\title{
PROSEDUR ANALISIS KELAYAKAN PEMBIAYAAN MIKRO: STUDI KASUS BRI SYARIAH CABANG PRABUMULIH
}

\author{
Selvy Safitri ${ }^{1}$ dan Arisson Hendry ${ }^{2}$
}

1 Staff Treasury Otomas Multifinance Syariah, Jakata. Email: selvysafitri22@gmail.com.

2 Kepala Inkopsyah dan Program Studi Perbankan Syariah, Sekolah Tinggi Ekonomi Islam SEBI, Depok, Jawa Barat. Email: arrison@inkopsyah.com

\begin{abstract}
ABSTRAK: Penelitian ini bertujuan untuk mengetahui bagaimana deskripsi prosedur Analisa kelayakan pembiayaan mikro pada BRISyariah Cabang Prabumulih. Metode penelitian yang digunakan adalah menggunakan metode kualitatif dengan dengan jenis penelitian deskriptif. Desain penelitian yang digunakan adalah studi kasus. Teknik pengumpulan data yang dijalankan adalah observasi langsung melalui magang kerja dan wawancara kepada pejabat bank divisi pembiayaan mikro cabang Prabumulih, mengambil datadata yang ada pada perusahaan, dan melakukan studi melalui buku-buku dan penelitian yang relevan. Penelitian ini mendeskripsikan bahwa prosedur analisa kelayakan pembiayaan mikro pada BRISyariah Cabang Prabumulih terdiri dari lima tahapan, yaitu: permohonan pembiayaan, pengumpulan berkas, analisa kelayakan pembiayaan, keputusan pembiayaan, dan pencairan pembiayan. Dari tahapan prosedur yang ada dapat disimpulkan bahwa Bank BRISyariah Cabang Prabumulih lebih mengedepankan prinsip kemudahan, kecepatan, kehati-hatian dan keamanan bagi pihak nasabah maupun bank.
\end{abstract}

Kata kunci: Prosedur, analisa kelayakan pembiayaan, pembiayaan mikro.

\begin{abstract}
The purpose of this research is to describe the prosedure of microfinance feasibility in BRI Syariah Branch of Prabumulih. This research used descriptive method and qualitatif data. To obtain data of this research, the writer used a direct observation by an internship program and an interview to the official of Bank of BRIsyariah Prabumulih. In addition, the study also used the relevant books. The result showed that, there are five procedures for analizing microfinance feasibility in BRISyariah branch of Prabumulih, namely financing application, file collection, analysis of financial feasibility, decisions, and disbursement. From the procedures, we can conclude that BRISyariah branch of Prabumulih emphasizes the principle of simplicity, speed, prudence and secure for customer and bank.
\end{abstract}

Keywords: Procedures, Financig feasibility Analisis, and micro financing 


\section{PENDAHULUAN}

Bank syariah merupakan lembaga keuangan yang memiliki fungsi intermediari, yaitu menghimpun dana dari masyarakat dan menyalurkannya kembali kepada masyarakat yang membutuhkan dana. Salah satu kegiatan utama dalam operasional bank syariah selain penghimpunan dana ialah peyaluran dana yang biasa disebut dengan istilah pembiayaan (Ikatan Bankir Indonesia, 2014, hlm. 202). Menurut Undang-Undang Perbankan Nomor 10 tahun 1998, pembiayaan adalah penyediaan uang atau tagihan yang dapat dipersamakan dengan itu, berdasarkan persetujuan atau kesepakatan antara bank dan pihak lain yang dibiayai untuk mengembalikan uang atau tagihan tersebut setelah jangka waktu tertentu dengan imbalan atau bagi hasil.

Kegiatan penyaluran dana berupa pembiayaan sebagai upaya dalam menggerakkan sektor riil telah mendapat perhatian tinggi dari perbankan syariah. Pada tahun 2012 sebesar $80,85 \%$ dari total penyaluran dana perbankan syariah atau sebesar Rp147,505 miliar diinvestasikan ke dalam aktivitas pembiayaan. Hal ini meningkat dari tahun ke tahun (Bank Indonesia, 2013). Kebijakan pengembangan perbankan syariah di Indonesia dalam jangka pendek lebih diarahkan pada pelayanan pasar domestik yang potensinya masih sangat besar terutama dalam sektor usaha mikro (Bank Indonesia). Pada bank syariah pembiayaan yang disalurkan ke usaha mikro umumnya menggunakan akad musyarakah yang memiliki porsi terbesar kedua setelah akad murabahah dibandingkan dengan akad lainnya (Bank Indonesia, 2014).

Penyaluran pembiayaan memberikan hasil yang paling besar diantara kegiatan penyaluran dana lainnya yang dilakukan oleh bank syariah. Seiring dengan tingginya hasil yang didapatkan tentunya resiko yang mungkin timbul dari proses penyaluran pembiayaan juga tinggi. Oleh karena itu, sebelum menyalurkan dana, bank syariah perlu melakukan serangkaian prosedur untuk menganalisa kelayakan pembiayaan yang diajukan oleh calon nasabah.

Salah satu bank syariah yang memiliki komitmen untuk membidik sektor usaha mikro sebagai segmentasi pasarnya adalah BRISyariah. Bank BRISyariah masih tergolong baru namun pertumbuhan asetnya tergolong sangat baik dan selalu meningkat dari waktu ke waktu. Pada tahun 2013 total aset yang dimiliki oleh BRISyariah mencapai 17 triliun rupiah dan dinobatkan sebagai bank dengan aset tertinggi nomor tiga setelah Bank Syariah Mandiri (BSM) dan Bank Muamalat Indonesia (BMI). Selain itu dana pihak ketiga yang dimiliki oleh bank BRISyariah meningkat sebanyak 13 triliun rupiah dengan jumlah penyaluran pebiayaan sebesar 14 triliun rupiah di tahun 2013. Sebagai sebuah badan usaha tentunya bank BRISyariah terlalu berani dalam menyalurkan pembiayaannya, hal tersebut terlihat dari dana yang disalurkan untuk pembiayaan lebih besar dari pada dana pihak ketiga yang dimiliki oleh bank. Namun dilihat dari tingkat Non performing Financing (NPF) yang dimiliki oleh bank BRISyariah pada tahun 2013 ialah sebesar 3,26\%, artinya bank BRISyariah masih tergolong aman dalam pengelolaan pembiayaan yang disalurkan (Publikasi Laporan Keuangan Tahunan BRISyariah, 2013).

Dalam menyalurkan pembiayaan pada sektor mikro BRISyariah memiliki kebijakan dan prosedur dimana terdapat pembagian tugas dan wewenang yang terkoordinir pada divisi mikro BRISyariah di setiap kantor cabang dan kantor cabang pembantu. Salah satu kantor cabang yang dinilai potensial karena letaknya yang strategis dengan pasar tradisional yang menjadi tempat para pelaku Usaha Mikro dan memiliki pengelolaan pembiayaan yang bagus dengan prosedur yang cukup ketat ialah BRISyariah kantor cabang Prabumulih. Hal ini ditunjukan dengan total pembiayaan mikro yang disalurkan terus meningkat dari sejak berdirinya kantor cabang tersebut, pada tahun 2013 total pembiayaan yang disalurkan adalah 8 miliar rupiah dengan tingkat NPF yang tetap tergolong baik yaitu sebesar 3\%. Kemudian pada tahun 2014 pembiayaan yang disalurkan 
Jurnal Ekonomi dan Perbankan Syariah

Vol. 3. No.1, April 2015: 37-54, ISSN (Print): 2330-2703

meningkat sebesar 12 miliar rupiah, dan pada tahun 2015 ditargetkan sebesar 14 miliar rupiah.

Berdasarkan latar belakang di atas, penulis tertarik untuk mengkaji mengenai pengaplikasian prosedur BRISyariah Kantor Cabang Prabumulih dalam menganalisis kelayakan pembiayaan mikro bagi para calon nasabah. Karena dengan prosedur dan Analisa yang tepat maka bank akan bisa meminimalisir risiko pembiayaan bermasalah. Oleh karena itu, penulis ingin mengetahui bagaimana prosedur kelayakan pembiayaan mikro pada BRISyariah Cabang Prabumulih

\section{TELAAH PUSTAKA}

\section{Bank Syariah}

Bank berasal dari bahasa Italia yaitu Banco (berarti bangku atau counter). (Karim, 2009). Menurut Undang-Undang Republik Indonesia Nomor 21 Tahun 2008 tentang perbankan syariah dinyatakan bahwa bank syariah adalah bank yang menjalankan kegiatan usaha berdasarkan prinsip syariah yang mengacu pada fatwa yang dikeluarkan oleh lembaga berwenang, dalam hal ini Dewan Syariah Nasional (DSN) di bawah Majelis Ulama Indonesia (MUI).

Perbankan syariah atau perbankan Islam adalah suatu sistem perbankan yang pelaksanaannya berdasarkan hukum Islam yaitu Al-Qur'an dan Al-Hadist (syariah). Pembentukan sistem ini berdasarkan adanya larangan dalam agama Islam untuk meminjamkan atau memungut biaya pinjaman dengan mengenakan bunga pinjaman (riba), serta larangan berinvestasi pada usaha-usaha yang dalam kategori terlarang (haram). Misalnya dalam usaha yang berkaitan dengan produksi makanan atau minuman haram, usaha media atau hiburan yang tidak Islami, dan lain-lain(Hesti, 2013, hlm. 19).

\section{Fungsi dan Peran}

Sesuai dengan Undang-Undang Republik Indonesia Nomor 21 Tahun 2008 tetang Perbankan Syariah, maka bank syariah memiliki fungsi dan peran yang dijelaskan sebagai berikut:

1) Penghimpun dana

Bank syariah dapat menghimpun dana dari masyarakat sesuai dengan fungsinya sebagai pengelola dana (mudharib) dalam bentuk simpanan.

2) Penyalur dana

Dana yang dihimpun disalurkan dalam bentuk pembiayaan atau bentuk lainnya dalam bentuk investasi pembelian sukuk (obligasi syariah), serta penyertaan dalam bentuk bagi hasil.

3) Pelayan jasa keuangan

Melakukan pelayanan lalu lintas pembayaran dilakukan dalam berbagai aktivitas, seperti pengiriman uang (transfer), inkaso, penagihan berupa collection, kartu kredit, kartu kredit syariah, transaksi tunai, Real Time Gross Settlement (RTGS), kliring (sistem kliring nasional), dan layanan perbankan lainnya.

\section{Pembiayaan}

Pembiayaan sangat bermanfaat bagi bank syariah, nasabah, dan pemerintah. Pembiayaan memberikan hasil paling besar diantara penyaluran dana dana lainnya yang dilakukan oleh bank syariah. Sebelum melakukan dana melalui pembiayaan, bank syariah perlu melakukan Analisa pembiayaan yang mendalam. (Ismail, 2011, hlm. 105) 


\section{Pengertian Pembiayaan}

Menurut Undang-Undang Perbankan No. 10 tahun 1998, pembiayaan adalah penyediaan uang atau tagihan yang dapat dipersamakan dengan itu, berdasarkan persetujuan atau kesepakatan antara bank dan pihak lain yang dibiayai untuk mengembalikan uang atau tagihan tersebut setelah jangka waktu tertentu dengan imbalan atau bagi hasil.

Pembiayaan merupakan salah satu tugas pokok bank, yaitu pemberian fasilitas penyediaan dana untuk memenuhi kebutuhan pihak-pihak yang merupakan defisit unit (Antonio, 2001, hlm. 160).

\section{Proses Pemberian Pebiayaan}

Proses pemberian fasilitas pembiayaan bank kepada nasabah dilakukan dengan secara cermat dengan tujuan agar bank mendapatkan keuntungan dengan resiko yang terukur. Proses pemberian pembiayaan secara sederhana tertuang dalam gambar berikut (Ikatan Bankir Indonesia, 2014, hlm. 223):

\section{Gambar 2. 1 Proses Pemberian Pembiayaan}
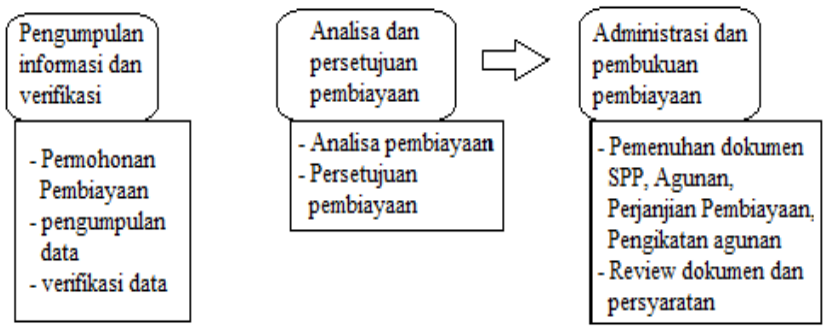

Setelah ada permohonan nasabah/calon nasabah, proses pemberian dari awal hingga akhir:

\section{Pengumpulan Informasi dan Dokumentasi}

Proses ini merupakan langkah awal dalam penyusunan Analisa pembiayaan untuk suatu proses pemberian fasilitas pembiayaan. Data dan informasi yang diperlukan dalam proses pembiayaan (Ikatan Bankir Indonesia, 2014, hlm. 224), antara lain:

1) Permohonan pembiayaan.

2) Dokumen perizinan/surat keterangan usaha.

3) Dokumen identitas nasabah.

4) Laporan keuangan.

5) Laporan pembiayaan nasabah (credit history) apabila sebelumnya nasabah pembiayaan telah mendapat fasilitas pinjaman dari bank

6) Fotokopi dokumen jaminan/agunan.

7) Dokumen lain yang diperlukan apabila ada.

\section{Verifikasi Data}

Proses pembiayaan yang baik dibangun dengan data dan informasi yang akurat untuk mendukung pengambilan keputusan pembiayaan yang tepat. Untuk itu, seluruh data dan informasi yang dikumpulkan perlu melewati suatu tahap verifikasi. Langkah tersebut diperlukan untuk memastikan keabsahan data dan kesesuaian dengan fakta. (Ikatan Bankir Indonesia, 2014, hlm. 225) 
Jurnal Ekonomi dan Perbankan Syariah

Vol. 3. No.1, April 2015: 37-54, ISSN (Print): 2338-2783

\section{Analisa dan Persetujuan Pembiayaan}

Analisa pembiayaan dilakukan melalui Analisa kualitatif dan kuantitatif untuk mendapatkan gambaran yang lengkap mengenai nasabah dan aktivitas usahanya (Ikatan Bankir Indonesia, 2014, hlm. 226). Tahapan Analisa pembiayaan dapat dijelaskan sebagai berikut:

\section{1). Analisa Kualitatif}

Analisa kualitatif meliputi Analisa terhadap aspek character dan capasity manajemen serta condition of economy (Ikatan Bankir Indonesia, 2014, hlm. 226).

1. Karakter

Analisa pertama dalam mengevaluasi proposal pembiayaan adalah Analisis character calon nasabah. Menilai karakter adalah pekerjaan yang paling sulit dalam Analisa pembiayaan (Jusuf, 2014, hlm. 323). Penilaian karakter calon nasabah pembiayaan dilakukan untuk menyimpulkan bahwa nasabah pembiayaan tersebut jujur, beritikad baik, dan tidak akan menyulitkan bank dikemudian hari (Ikatan Bankir Indonesia, 2014). Penilaian karakter lazimnya dilakukan melalui (Jusuf, 2014, hlm. 325):

1) Informasi dari catatan internal bank sendiri. Hal tersebut berlaku terutama jika calon nasabah yang telah atau pernah memiliki hubungan dengan bank, dokumen pembiayaan, mutasi, dan kualitas transaksi sehari-hari.

2) Trade checking, yaitu mencari informasi tentang calon nasabah dari rekan-rekan bisnisnya. Misalnya para pemasok, pelanggan, atau masyarakat sekitar.

3) Bank checking, yakni mencari informasi dari bank lain yang mungkin pernah berhubungan langsung dengan nasabah dalam pembiyaaan dan lainnya.

4) BI checking, yaitu Bank Indonesia (BI) telah mengembangkan suatu sistem informasi debitur (SID) yang tersambung secara komputerisasi. Bank dapat meminta data tertentu mengenai calon nasabah yang datanya ada ada di database BI. Referensi BI checking ini merupakan data yang akurat dan sangat membantu bank dalam melakukan Analisa pembiayaan.

\section{Capacity}

Penelitian kemampuan calon nasabah pembiyaaan dalam bidang usahanya dan/atau kemampuan manajemen nasabah pembiayaan agar bank yakin bahwa usaha yang diberikan pembiayaan tersebut dikelola oleh orang-orang yang tepat. Pendekatan yang dapat digunakan dalam menilai capasity nasabah, antara lain (Ikatan Bankir Indonesia, 2014, hlm. 204):

1. Pendekatan historis, yaitu menilai kinerja calon nasabah di masa lalu (past performance.)

2. Pendekatan financial, yaitu menilai kemampuan keuangan calon nasabah pembiayaan.

3. Pendekatan yuridis, yaitu melihat secara yuridis person yang berwenang mewakili calon nasabah pembiayaan dalam melakukan penandatanganan perjanjian pembiayaan dengan bank.

4. Pendekatan manjaerial, yaitu menilai kemampuan nasabah dalam melaksanakan fungsi manajemen dalam memimpin perusahaan.

5. Pendekatan teknis, yaitu menilai kemampuan calon nasabah pembiayaan terkait teknis produksi, seperti tenaga kerja, sumber bahan baku, perlatan, administrasi, keuangan, dan lain-lain. 
3. Condition of economy (Ikatan Bankir Indonesia, 2014, hlm. 205)

Penilaian atas kondisi pasar di dalam negeri maupun di luar negeri, baik masa lalu maupun masa yang akan datang, dilakukan untuk mengetahui prospek pemasaran dari hasil usaha nasabah pembiayaan yang dibiayai. Beberapa hal yang dapat dipergunakan dalam menganalisa condition of economy, antara lain:

1) Regulasi pemerintah pusat dan daerah.

2) Kondisi makro dan mikro ekonomi.

3) Situasi politik dan keamanan.

4) Kondisi lain yang mempengaruhi pemasaran.

\section{2). Analisa Kuantitatif}

Analisa kuantitatif dilakukan melalui penilaian atas aspek capital dan keuangan nasabah. Aspek kuantitatif yang di analisa antara lain (IBI, 2014, hlm. 229):

1) Neraca, menunjukkan jumlah aktiva, utang, dan modal perusahaan.

2) Laporan laba/rugi, menunjukkan jumlah pendapatan dan biaya yang dikeluarkan pada suatu periode tertentu.

3) Laporan sumber dan penggunaan dana, Analisa ini menjadi sangat penting karena dengan informasi ini bank dapat mengetahui kebijaksaan pembelanjaan yang diambil peusahaan pada periode yang bersangkutan.

\section{Analisa Jaminan (collateral)}

Analisa jaminan merupakan bentuk evaluasi terhadap aspek collateral. Analisa terhadap jaminan merupakan Analisa terhadap agunan pembiayaan dan sumber keuangan lain yang dapat digunakan sebagai alternatif sumber pengembalian pembiayaan. Analisa digunakan untuk mengetahui kecukupan nilai agunan pemberian pembiayaan (Ikatan Bankir Indonesia, 2014, hlm. 229).

\section{Kepatuhan Syariah}

Sebagai upaya pengendalian, meskipun suatu lembaga telah menyandang nama syariah, namun tidak menutup kemungkinan dalam menjalankan usahanya menyimpang dari nama yang disandang tersebut. Dalam menjalankan usahanya bank berdasarkan prinsip-prinsip syariah berupaya menjaga dan memelihara agar prinsip-prinsip syraiah tersebut tetap terpelihara dalam operasionalnya. Hal-hal yang diperhatikan sebelum menyetujui usul pembiayaan tersebut, antara lain:

1) Apakah objek pembiayaan halal atau haram.

2) Apakah objek pembiayaan menimbulkan kemudharatan bagi masyarakat.

3) Apakah berkaitan dengan perbuatan mesum/ asusila.

4) Apakah objek berkaitan dengan perjudian.

5) Apakah usaha itu berkaitan dengan industri senjata ilegal atau berorientasi pada pembangunan senjata pemusnah massal.

6) Apakah usaha tersebut dapat merugikan pihak Islam baik secara langsung atau tidak langsung (Sutedi, 2009).

\section{Administrasi dan Pembukuan Pembiayaan}

Tahap lanjutan setelah pembiayaan disetujui adalah proses administrasi dan pembukuan yang meliputi beberapa proses (Ikatan Bankir Indonesia, 2014, hal 231-232):

1. Surat Pemberitahuan Keputusan Pembiayaan. Setelah pembiayaan diputus, bank akan menerbitkan Surat Pemberitahuan Keputusan Pembiayaan (SPKP) untuk nasabah. 
2. Perjajian Pembiayaan. Merupakan perikatan secara tertulis antara bank dengan nasabah pembiayaan dengan jenis akad yang disepakati yang mengatur hak dan kewajiban para pihak sebagai akibat adanya transaksi pembiayaan.

3. Pengikatan Agunan. Setelah penandatanganan perjanjian pembiayaan dilakukan, bank akan mendapatkan dokumen agunan untuk dilakukan pengikatan. Dokumentasi/pengikatan agunan harus lengkap agar tidak menimbulkan masalah yang tidak dikehendaki.

4. Penutupan Asuransi Agunan. Salah satu upaya mengamankan agunan dan memperkecil resiko pembiayaan adalah meng-cover atau menutup agunan pembiayaan dengan asuransi.

\section{Disbursement (Pencairan Pembiayaan)}

Tahapan pencairan pembiayaan adalah tahapan saat fasilitas pembiayaan diserahkan kepada nasabah dalam bentuk pencairan dana pembiayaan. Pencairan dilakukan setelah dipastikan bahwa seluruh dokumentasi dan persyaratan pembiayaan telah dipenuhi nasabah (Ikatan Bankir Indonesia, 2014). Pembiayaan yang baik adalah pembiayaan yang disalurkan kepada calon nasabah yang mau dan mampu memenuhi kewajibannya ketidakhadiran dari salah satu aspek akan mengakibatkan pembiayaan bermasalah atau gagal bayar (Jusuf, 2014).

\section{Pembiayaan Mikro}

Menurut Undang-Undang Republik Indonesia Nomor 20 Tahun 2008 tentang usaha mikro, kecil, dan menengah bahwa Pembiayaan adalah penyediaan dana oleh Pemerintah, Pemerintah Daerah, Dunia Usaha, dan masyarakat melalui bank, koperasi, dan lembaga keuangan bukan bank, untuk mengembangkan dan memperkuat permodalan Usaha Mikro, Kecil, dan Menengah.

Menurut International Management Communications Corporation (IMCC), microfinance atau pembiayaan mikro sebagai seperangkat teknik dan metode perbankan non-tradisional untuk membuka akses seluas-luasnya kepada sektor yang tidak tersentuh jasa keuangan formal (Hadinoto, 2007). Pembiayaan mikro adalah fasilitas pembiayaan yang diberikan untuk membiayai kegiatan usaha mikro (Ikatan Bankir Indonesia, 2014).

Kesimpulannya, dari semua definisi tentang pembiayaan mikro maka dapat diketahui bahwa pembiayaan mikro ialah pembiayaan yang ditujukan untuk sektor mikro sebagaimana yang dimaksud dalam Undang-Undang Nomor 20 tahun 2008 tentang usaha mikro, kecil, dan menengah.

\section{Usaha Mikro}

Menurut Undang-Undang Republik Indonesia Nomor 20 Tahun 2008 tentang usaha mikro, kecil, dan menengah bahwa Usaha Mikro adalah usaha produktif milik orang perorangan dan/atau badan usaha perorangan yang memenuhi kriteria usaha mikro sebagaimana diatur dalam Undang-Undang ini. Kriteria Usaha Mikro adalah sebagai berikut:

1) Memiliki kekayaan bersih paling banyak Rp50.000.000,00 (lima puluh juta rupiah) tidak termasuk tanah dan bangunan tempat usaha; atau

2) Memiliki hasil penjualan tahunan paling banyak Rp300.000.000,00 (tiga ratus juta rupiah). 


\section{METODE PENELITIAN}

Jenis penelitian ini bersifat deskriptif dan kualitatif yang menggunakan field research (penelitian lapangan) dengan cara pengamatan langsung ke kantor PT BRISyariah Cabang Prabumulih untuk memperoleh data primer dengan teknik magang kerja sekaligus wawancara pihak terkait mengenai alur analisa kelayakan pembiayaan mikro di Unit Mikro Syariah PT BRISyariah Cabang Prabumulih. Data sekunder adalah pelengkap data primer berupa dokumentasi, catatan arsip, serta hasil kajian pustaka dari buku - buku yang relevan. Lokasi Penelitian ini berada di Kantor Cabang PT BRISyariah Prabumulih.

\section{HASIL DAN ANALISIS}

\section{Sejarah Singkat Perusahaan}

Berawal dari akuisisi PT. Bank Rakyat Indonesia (Persero), Tbk., terhadap Bank Jasa Arta pada 19 Desember 2007 dan setelah mendapatkan izin dari Bank Indonesia pada 16 Oktober 2008 melalui suratnya o.10/67/KEP.GBI/DpG/2008, maka pada tanggal 17 November 2008 PT. Bank BRI Syariah secara resmi beroperasi. Kemudian PT. Bank BRI Syariah merubah kegiatan usaha yang semula beroperasional secara konvensional, kemudian diubah menjadi kegiatan perbankan berdasarkan prinsip syariah Islam.

Aktivitas PT. Bank BRI Syariah semakin kokoh setelah pada 19 Desember 2008 ditandatangani akta pemisahan Unit Usaha Syariah PT. Bank Rakyat Indonesia (Persero), Tbk., untuk melebur ke dalam PT. Bank BRI Syariah (proses spin off) yang berlaku efektif pada tanggal 1 Januari 2009. Saat ini PT. Bank BRI Syariah menjadi bank syariah ketiga terbesar berdasarkan aset. PT. Bank BRI Syariah tumbuh dengan pesat baik dari sisi aset, jumlah pembiayaan dan perolehan dana pihak ketiga. Dengan berfokus pada segmen menengah bawah, PT. Bank BRI Syariah menargetkan menjadi bank ritel modern terkemuka dengan berbagai ragam produk dan layanan perbankan (brisyariah.co.id).

\section{Visi dan Misi Perusahaan}

Visi "Menjadi bank ritel modern terkemuka dengan ragam layanan finansial sesuai kebutuhan nasabah dengan jangkauan termudah untuk kehidupan lebih bermakna".

\section{Misi}

1) Memahami keragaman individu dan mengakomodasi beragam kebutuhan finansial nasabah.

2) Menyediakan produk dan layanan yang mengedepankan etika sesuai dengan prinsip-prinsip syariah.

3) Menyediakan akses ternyaman melalui berbagai sarana kapan pun dan dimana pun.

4) Memungkinkan setiap individu untuk meningkatkan kualitas hidup dan menghadirkan ketenteraman pikiran.

Sedangakan untuk jaringan pelayanannya tersebar diseluruh Indonesia dengan 52 Kantor Cabang, 199 Kantor Cabang Pembantu, 8 Kantor Kas, 573 Kantor Layanan Syariah

\section{Prosedur Analisa Kelayakan Pembiayaan Mikro BRISyariah Cabang Prabumulih}

Pemberian fasilitas pembiayaan yang dilakukan bank BRISyariah kepada calon nasabahnya dapat dilakukan setelah melalui beberapa tahapan hingga pencairan pembiayaan dapat dilakukan. Berdasarkan hasil wawancara dengan para pejabat 
Jurnal Ekonomi dan Perbankan Syariah

Vol. 3. No.1, April 2015: 37-54, ISSN (Print): 2330-2783

pelaksana pembiayaan mikro, maka penulis dapat mengemukakan bahwa prosedur pembiayaan dilakukan secara bertahap yaitu sebagai berikut: (Violeta, 2014)

\section{Tahap permohonan pembiayaan \\ Prospek Nasabah}

Pada tahapan awal permohonan pembiyaaan pihak bank yaitu Sales Officer yang selanjutnya disebut SO yang merupakan bagian staff marketing akan melakukan prospek kepada calon nasabah yang selanjutnya disebut CN. Tahapan ini dilakukan dengan dua cara:

\section{Ngampas}

Istilah ngampas digunakan oleh Bank BRISyariah cabang Prabumulih untuk Memudahkan pemahaman mengenai proses pencairan nasabah ini. Cara ini dilakukan dengan membagikan brosur ke lokasi-lokasi strategis seperti ruko-roko dan pedagang di pasar, dan dengan cara berbelanja di ruko-ruko atau tempat usaha CN yang sudah dibidik kemudian mulai menawarkan pembiayaan secara tidak langsung.

2. Nasabah Referensi

Cara ini dilakukan dengan cara menghubungi CN yang didapat dari referensi nasabah sebelumnya atau karyawan BRISyariah.

Kedua cara untuk memprospek $\mathrm{CN}$ tersebut sudah dilakukan oleh tim marketing lending pembiayaan mikro BRISyariah cabang Prabumulih sejak awal BRISyariah cabang Prabumulih dibuka. Dari kedua cara tersebut, yang paling banyak menjaring CN pembiayaan ialah cara ngampas.

Setelah melakukan prospek CN pembiayaan mikro, selanjutnya setiap CN pembiayaan akan diidentifikasi apakah masuk dalam radius 15 KM dari Unit Mikro Syariah (UMS) BRISyariah atau tidak. Sesuai dengan prosedur persyaratan pembiayaan mikro BRISyariah, hanya CN yang masuk dalam radius $15 \mathrm{KM}$ dari UMS yang boleh diproses oleh cabang yang bersangkutan. Hal tersebut dimaksudkan untuk efisiensi waktu , dan biaya yang harus dikeluarkan oleh BRISyariah.

Setelah dipastikan bahwa CN masuk dalam radius $15 \mathrm{KM}$ dari unit mikro syariah (UMS) maka selanjutnya SO akan melakukan verifikasi awal melalui obrolan-obrolan dan melihat-lihat keadaan keadaan tempat usaha $\mathrm{CN}$, dari proses ini akan dapat dilihat apakah CN layak atau tidak untuk diproses secara lebih lanjut.

\section{Aplikasi Permohonan Pembiayaan}

Pada tahapan ini CN mengajukan permohonan pembiayaan mikro secara tertulis kepada pihak BRI Syariah dengan melampirkan data dan dokumen yang dipersyaratkan. Permohonan pembiayaan dapat dilakukan dengan dua cara, yang pertama CN datang langsung ke kantor cabang BRISyariah Prabumulih dan dibantu oleh Customer Service selanjutnya disebut CS untuk memberikan penjelasan tentang produk pembiayaan mikro secara umum. Namun jika nasabah tidak dapat datang ke kantor langsung, maka pihak SO akan mengunjungi nasabah dan menjelaskan mengenai produk pembiayaan mikro secara rinci serta memberikan formulir pembiayaan untuk disiisi lengkap. Pelayanan ini merupakan bagian fasilitas pick up service dari BRISyariah Cabang Prabumulih untuk memudahkan CN dalam mengajukan pembiayaan.

Disamping pengisisan formulir pengajuan pembiayaan $\mathrm{CN}$ juga harus memenuhi persyaratan yang telah ditetapkan dalam hal pengajuan permohonan pembiayaan. Selain 
itu, setelah mengisi lengkap formulir pengajuan pembiayaan dan dinilai memenuhi persyaratan umum, CN akan diminta untuk memenuhi seluruh persyaratan dokumen yang sudah ditetapkan. Adapun persyaratan dokumen tersebut adalah:

1. Fotocopy data induk berupa; KTP CN dan pasangan, Kartu keluarga, dan akta nikah.

2. Surat Izin Usaha Perusahaan (SIUP)

3. Bagi pembiayaan mikro Rp. 75 juta hingga Rp. 500 juta maka harus menyertakan NPWP.

NPWP dibutuhkan hanya untuk pembiayaan mikro $\geq$ Rp. 75 juta, dengan alasan bahwa seseorang yang mengajukan pembiayaan sebesar itu maka memiliki penghasilan di atas rata-rata, maka seharusnya sudah memiliki NPWP (Nomor Pokok Wajib Pajak) karena telah berkewajiban membayar pajak sebagai seorang WNI.

Dalam realisasinya keseluruhan dokumen persyaratan tersebut haruslah dilengkapi tanpa terkecuali dalam proses analisa pembiayaan, berikut merupakan deskripsi realisasi dokumen tersebut:

1. Fotocopy data induk nasabah; data- data ini dibutuhkan agar pihak bank bisa mendapatkan informasi identitas CN yang valid. KTP CN dan pasangan dibutuhkan sebagai dasar identitas kependudukan CN yang membuktikan bahwa CN ialah warga negara Indonesia resmi dan memudahkan penelusuran untuk menjalankan fasilitas BI checking. Fotocopy akta nikah diperlukan karena pasangan dari CN juga akan ikut bertanggung jawab terhadap pembiayaan $\mathrm{CN}$.

2. SIUP (Surat Izin Usaha Perusahaan). Dokumen ini menjadi salah satu yang sangat penting, karena SIUP menjadi bukti legal kepemilikan dan operasi usaha $\mathrm{CN}$, dalam arti lain usahanya terdaftar secara resmi pada dinas terkait.

3. Nomor Pokok Wajib Pajak (NPWP). Dokumen ini dibutuhkan hanya untuk CN dengan plafon lebih dari 75 juta. Karena CN yang mengajukan pembiayaan sebesar itu diasumsikam sudah terkena kewajiban membayar pajak sebagai seorang WNI. Identitas yang ada di kantor pajak merupakan identitas resmi yang juga memuat bagaimana kinerja keuangan usaha CN. Sehingga akan memudahkan pihak bank mengidentifikasi kesanggupan $\mathrm{CN}$ dalam repayment pembiayaan.

\section{Document Checklist (DCL)}

Setelah semua berkas dilengkapi oleh CN, pihak SO akan membuat Document Checklist yang selanjutnya disebut DCL. Setiap dokumen yang sudah ada akan diberikan tanda checklist pada setiap kolom DCLnya begitu selanjutnya, kemudian jika sudah lengkap maka akan diberi paraf sebagai tanda verifikasi dari SO. DCL berfungsi untuk mengetahui dan memastikan kelengkapan pengumpulan berkas CN yang menjadi persyaratan pengajuan pembiayaan mikro, sekaligus memudahkan tahapan screening.

\section{BI Checking}

Permohonan BI checking seharusnya diajukan ke financial support, namun berbeda dengan BRISyariah cabang Prabumulih, BI checking diajukan ke Unit Financing Officer yang selanjutnya disebut UFO. Hasil dari BI checking menunjukkan kualitas pembiayaan, berupa tingkat kolektabilitas pembiayaan yang pernah dilakukan oleh $\mathrm{CN}$ di bank atau 
Jurnal Ekonomi dan Perbankan Syariah

Vol. 3. No.1, April 2015: 37-54, ISSN (Print): 2330-2703

lembaga lainnya juga untuk mempermudah pihak bank untuk menganalisa apakah nasabah layak atau tidak diberikan pembiayaan.

Dalam realisasinya untuk mempercepat proses, BI checking akan dilakukan oleh relation officer yang selanjutnya disebut RO, namun tetap atas pengawasan otorisasi UFO. Proses BI checking membutuhkan waktu setengah hari kerja (3 jam), dilihat dari kondisi jaringan dan banyaknya berkas. Hasil BI checking akan dimasukkan ke dalam berkas aplikasi permohonan pembiayaan.

Setelah semua aplikasi lengkap; aplikasi permohonan pembiayaan, dokumendokumen persyaratan, DCL sudah penuh di checklist dan diparaf, serta hasil BI checking, SO akan menyatukan semuanya dalam satu map dan diserahkan pada UFO. Apabila masih ada yang belum lengkap maka SO bertugas meminta pada CN untuk segera melengkapi dokumen yang kurang. Waktu yang diperlukan untuk keseluruhan proses permohonan pembiayaan ini tidak dapat dipastikan, karena hal ini bergantung pada waktu yang diperlukan nasabah untuk mengumpulkan semua berkas persyaratan.

\section{Tahap Analisa Pembiayaan}

Pada tahap ini analisa pembiayaan bagi CN dilakukan oleh unit micro financing, meliputi:

1. Sales Officer (SO), bertugas sebagai investigator dalam proses investigasi.

2. Unit Financing Officer (UFO), bertugas sebagai interviewer dan penyusun semua dokumen yang dibutuhkan dalam proses analisa sekaligus analis kelayakan pembiayaan.

3. Unit Head (UH), bertugas sebagai verifier dan authorize (khusus untuk pembiayaan dibawah 75 juta)

4. Pincapem, bertugas sebagai verifier dan authorize (khusus untuk pembiayaan diatas 75 juta)

Adapun proses dari tahapan analisa pembiayaan mikro adalah sebagai berikut:

\section{Screening}

Dalam tahapan ini UFO akan melakukan screening atau yang lebih dikenal dengan sortir berkas sekaligus menginvestigasi keabsahan berkas yang dikumpulkan CN. Proses ini dilakukan dengan mencocokkan semua data (fotocopy) yang diserahkan nasabah pada tahap awal dengan aslinya, sebagai bentuk validasi dokumen identitas nasabah. Dalam tahap ini akan bisa diidentifikasi apabila ada berkas legal nasabah yang dimanipulasi, misalnya data diri yang ada di KTP tidak sama dengan yang ada di NPWP atau surat nikah, maka perlu diselidiki ke pihak yang berwenang apakah memang terjadi kesalahan atau CN memalsukan datanya.

Apabila CN terbukti melakukan pemalsuan terhadap data yang dikumpulkan, maka BRISyariah akan langsung menolak permohonan pembiayaan yang diajukan sekaligus mem-blacklist CN yang bersangkutan, karena hal ini merupakan bagian dari verifikasi karakter dalam proses analisa kelayakan pembiayaan.

\section{Survei CN}

Sebelum melakukan investigasi langsung ke lokasi CN unit micro financing akan melakukan briefing untuk memastikan DCL sudah ter-checklist dan aplikasi pembiayaan sudah disiapkan, serta persamaan visi dan misi dalam melakukan investigasi ke CN. Briefing dilakukan secara singkat $( \pm 15$ menit $)$ namun teliti. 
Proses survei ini dilakukan dengan dua cara yaitu wawancara atau interview dan investigasi langsung ke lingkungan sekitar lokasi usaha atau tempat tinggal CN. Adapun pertanyaan yang akan diajukan dalam wawancara atau interview adalah sebagai berikut:

1. Menanyakan tujuan pembiayaan, hal ini dimaksudkan untuk mengetahui pemanfaatan dana pembiayaan yang akan diberikan oleh bank.

2. Menanyakan hal-hal yang berhubungan dengan Analisa kualitatif usaha CN, seperti: jenis usaha, latar belakang usaha, perkembangan usaha, pesaing, distributor, dan lain-lain.

3. Menanyakan hal-hal yang berhubungan dengan Analisa kuantitatif usaha nasabah, seperti: keuntungan atau laba dari hasil usaha CN untuk mengetahui kemampuan bayar nasabah. Laporan arus kas, jumlah aset, dan lain-lain yang mencerminkan keuangan nasabah. Biasanya $\mathrm{CN}$ juga tidak melakukan pencatatan terhadap keuangan usahanya, sehingga dalam proses wawancara ini lah tim marketing harus mampu mencari informasi mengenai penghasilah dan pengeluaran berikut beban-beban keuangan $\mathrm{CN}$.

4. Menanyakan rencana angsuran pembiayaan jika pembiayaan wanprestasi, dan apakah ada way out (jalan keluar - punya pilihan lain) untuk melunasi pembiayaan jika terjadi wanprestasi.

5. Menanyakan hubungan nasabah dengan bank, apakah nasabah pernah mengajukan pembiayaan di bank lain dan lain-lain, atau apakah CN sudah menjadi nasabah di BRISyariah sebelumnya.

Selain wawancara pihak SO akan melakukan investigasi ke lokasi usaha yang akan dibiayai dan tempat tinggal $\mathrm{CN}$ dengan melihat langsung kondisi ekonomi CN dan menjaring informasi berupa opini dari lingkungan sekitar tempat tinggal dan usaha CN. Bagaimana hubungan $\mathrm{CN}$ dengan lingkungan sekitarnya, tetangga, pejabat setempat (RT, RW, Lurah), distributor, atau pesaingnya.

Hal ini dimaksudkan untuk mengetahui karakter nasabah melalui tanggapan subjektif dari masyarakat terdekat. Saat melakukan investigasi biasanya akan diperoleh informasi misalnya, apakah usaha nasabah selalu ramai pengunjung atau berapa lama kira-kira usaha nasabah sudah berjalan, bagaimana tanggapan masyarakat tentang sikap nasabah kepada pelanggan, dan lain-lain.

\section{Menaksir jaminan}

Dalam menganalisa layak atau tidaknya seorang $\mathrm{CN}$ untuk diberikan pembiayaan pihak bank akan melihat apa yang akan dijadikan jaminan oleh CN selama mengambil pinjaman dari bank. Pada umumnya jaminan tidak hanya berbentuk kebendaan tapi juga bisa yang tidak berwujud seperti jaminan pribadi (goodwill), letter of guarantee, dan lainlain.

Dalam realisasinya, bank BRISyariah lebih menekankan pada jaminan yang berbentuk kebendaan, terutama bangunan rumah, ruko, atau tanah. Ini menunjukkan bahwa BRISyariah memilih untuk memprioritaskan keamanan dalam menyalurkan pembiayaan kepada CN. Pihak bank juga akan menyampaikan bahwa pada saat penyerahan jaminan (surat kepemilikannya jika yang dijaminkan adalah rumah, ruko, atau tanah) maka pasangan $\mathrm{CN}$ harus diajak ikut serta, hal ini dimaksudkan agar pasangan CN mengetahui pembiayaan yang diajukan. Pihak bank akan menanyakan perihal jaminan yang dipunyai nasabah, mengenai kepemilikannya, deskripsi benda 
Jurnal Ekonomi dan Perbankan Syariah

Vol. 3. No.1, April 2015: 37-54, ISSN (Print): 2330-2703

tersebut (warna, merk, tahun, dan lain-lain), lokasi, perkiraan nilai, surat-surat legal kepemilikan dan lain-lain. Dalam mentaksirkan nilai jaminan yang diberikan oleh CN biasanya pihak bank akan melihat dari dua sisi, sebagai berikut:

1. Segi ekonomis yaitu dengan melihat nilai ekonomis atau nilai pasar dari barangbarang yang akan dijadikan jaminan oleh CN.

2. Segi yuridis yaitu apakah jaminan tersebut memenuhi syarat-syarat hukum yang diperlukan untuk dipakai sebagai jaminan yang diagunkan.

Umumnya, jumlah jaminan haruslah lebih besar dari jumlah pinjaman yang diberikan oleh bank. Dari hal tersebut diatas, dapat disimpulkan bahwa pihak BRISyariah cenderung mengutamakan segi keamanan dalam menyalurkan pembiayaannya kepada nasabah.

\section{Laporan Hasil Survei}

Setelah melakukan survei langsung ke nasabah, UFO yang bertindak sebagai analis akan menganalisa semua informasi yang masuk dari aspek kualitatif maupun aspek kuantitatif, untuk kemudian dirangkum dalam beberapa berkas, yaitu: Lembar Kunjungan Nasabah (LKN), Memorandum Usulan Pembiayaan (MUP), dan LPBJ (Lembar Pemeriksaan Barang jaminan).

\section{Lembar Kunjungan Nasabah}

Lembar Kunjungan Nasabah yang selanjutnya disebut LKN memuat hasil analisa kondisi real nasabah secara kualitatif dan kuantitatif berdasarkan survei yang sudah dilakukan. Dalam realisasinya, pada umumnya CN pembiayaan mikro tidak mempunyai laporan keuangan usahanya, oleh karena itu pihak bank akan berinisiatif merangkum hasil wawancara dan investigasinya mengenai angka penghasilan rata-rata yang didapatkan nasabah menjadi sebuah laporan keuangan. Untuk beban-beban yang harus dibayar pihak bank akan meminta tanda bukti pembayaran beberapa bulan terakhir, seperti listrik, dll.

LKN ini dibutuhkan untuk mengetahui sekaligus mengevaluasi kondisi perekonomian nasabah, juga untuk memastikan apakah CN layak atau tidak untuk diusulkan menerima pembiayaan.

\section{Memorandum Usulan Pembiayaan}

Memorandum Usulan Pembiayaan yang selanjutnya disebut MUP merupakan usulan dari pihak UFO kepada delegasi pejabat bank mengenai kondisi nasabah agar pembiayaan tersebut dapat disetujui atau diotorisasi. Salah satu cara menyimpulkan hasil analisa yang sudah dilakukan adalah Analisa $5 \mathrm{C}+\mathrm{S}$.

\section{Character}

Merupakan penilaian terhadap diri CN berupa sifat dan wataknya. Hal ini bertujuan untuk memberikan keyakinan kepada pihak bank bahwa CN pembiayaan dapat dipercaya. Karakter merupakan faktor yang dominan, walaupun CN memiliki kemampuan untuk membayar hutang namun tidak mempunyai itikad baik untuk melunasinya tentu akan membawa kesulitan bagi pihak bank dikemudian hari.

Sifat atau watak CN dapat tercermin dari sikap yang ia tunjukan pada saat wawancara, apakah $\mathrm{CN}$ bersikap tenang dan terbuka saat diwawancarai atau tidak, gaya bicaranya dalam wawancara, dan bagaimana $\mathrm{CN}$ memandang nilai pembiayaan. Hasil investigasi yang dilakukan pihak bank juga akan memberikan kesimpulan apakah CN itu mempunyai karakter yang yg baik dan loyal atau sebaliknya. 
Selain itu BI checking juga akan membantu menyimpulkan bagaimana prestasi pembiayaan yang pernah dilakukan oleh nasabah. Untuk nasabah lama atau yang sudah pernah mengajukan pembiayaan di BRISyariah, maka UFO akan melihat prestasi pembiyaaan sebelumnya, bagaimana riwayat penyetoran angsuran pembiayaannya.

2. Capital

Pada praktiknya modal yang dimiliki oleh CN nilainya paling tidak 30\% dari nilai pinjaman yang diajukan ke bank. Selain itu dengan persyaratan bahwa CN tidak mempunyai pinjaman di bank lain, karena dikhawatirkan apabila CN memiliki pinjaman di bank lain maka CN akan kesulitan dalam melunasi pembiayaan yang diajukannya. Dalam realisasinya, komponen ini tidak terlalu diperhatikan oleh pihak bank.

\section{Capacity}

Merupakan kemampuan nasabah untuk menjalankan usahanya dan mengelola keuangannya untuk kemudian CN dapat mengembalikan pinjaman yang ia ambil dari bank. Dalam menilai capacity atau kapasitas yang dimiliki oleh CN, bank harus melakukan survei langsung ke lokasi usaha nasabah untuk melihat langsung kondisi usaha CN. Apakah usaha yang dijalankan nasabah merupakan usaha pokok atau bukan, apakah ada sumber keuangan lainnya, apakah usaha tersebut sudah berjalan lebih dari 2 tahun atau belum, apakah bahan yang diperoleh untuk usaha nasabah mudah didapat atau tidak, bagaimana prospeknya, apakah omset yang didapat stabil, dan lain-lainnya.

\section{Collateral}

Merupakan jaminan yang akan diberikan nasabah selama mengambil pinjaman dari bank. Realisasinya, BRISyariah lebih menekankan pada jaminan yang berbentuk kebendaan, khususnya bangunan atau tanah. Biasanya nilai jaminan harus lebih besar daripada nilai pinjaman yang diajukan oleh CN. Dalam proses penyerahan jaminan harus dipastikan bahwa keluarga, terutama istri bersedia ikut menjadi penjamin. Hal ini menunjukkan bahwa BRISyariah lebih mengutamakan prinsip keamanan dalam menyalurkan dana untuk pembiayaan kepada CN pembiayaan.

\section{Condition of economy}

Yaitu situasi atau keadaan lingkungan usaha dalam bidang ekonomi, politik, dan budaya yang dapat mendukung kelancaran usaha nasabah. Dalam menganalisa hal ini biasanya bank akan berusaha mendapatkan informasi mengenai pasang surut harga di pasaran, izin untuk mengeluarkan produk yang dijual, izin tempat usaha, apakah usaha nasabah diterima oleh adat istiadat masyarakat setempat, dan lain-lain.

Dalam realisasinya, bank akan melihat kondisi ekonomi pada saat itu, hanya saja komponen ini tidak menjadi yang sangat diprioritaskan, terkecuali jika tergambar dengan jelas memang daerah tersebut sedang krisis perekonomiannya. Biasanya komponen ini akan serta merta di checklist tanpa peninjauan yang mendalam.

\section{Syariah}

Aspek ini mengacu pada keadaan usaha yang dijalankan oleh nasabah, apakah operasional dan produk yang dihasilkan oleh usaha tersebut halal atau tidak dan apakah memenuhi kepatuhan syariah. Dalam realisasinya, apabila jenis usahanya sudah terkategori halal aspek ini langsung di checklist, tidak ada peninjauan lebih lanjut mengenai bahan baku dan lain sebagainya. 
Jurnal Ekonomi dan Perbankan Syariah

Vol. 3. No.1, April 2015: 37-54, ISSN (Print): 2338-2783

\section{Tahap Pemberian Keputusan Pembiayaan}

Sebelum keputusan akhir diterima atau tidaknya pengajuan pembiayaan UFO terlebih dahulu akan memberikan gambaran keputusan sebelum mengajukan memorandum usulan pembiayaan (MUP) untuk diotorisasi. Gambaran keputusan yang dimaksud mencangkup 3 (tiga) hal:

1. Disetujui sesuai dengan plafon pengajuan nasabah, artinya bank menyetujui jumlah keseluruhan permohonan pembiayaan yang diajukan oleh nasabah.

2. Disetujui dengan ketentuan plafon diturunkan, hal ini disebabkan nasabah kurang memenuhi aspek 5C dan 1S (Character, Capital, Capacity, Collateral, Condition of Economy, dan Syariah) dengan mengutamakan aspek Character, Capacity, dan Collateral. Misalnya nasabah mempunyai karakter yang baik dilihat dari respond dan jawaban yang diberikan saat interview dan dari hasil BI Checking yang dilakukan oleh bank. Nasabah juga mempuyai usaha yang halal, manajemen usaha yang bagus dilihat dari keterangan karyawannya dan arus keuangan usahanya. Jaminan yang dijaminkan nasabah juga mencukupi apabila muncul kemungkinan gagal bayar nasabah dalam pembiayaan. Jika dilihat dari data laporan keuangan nasabah per-bulannya tidak mencukupi tetap diterima. Namun ketentuan penurunan plafon dari jumlah yang diajukan.

3. Permohonan tidak disetujui. Kemungkinan terakhir ini akan muncul apabila nasabah diketahui memiliki karakter yang kurang baik, kapasitas yang tidak mencukupi, nilai collateral atau jaminan yang tidak sesuai dengan jumlah pinjaman atau usaha yang dijalankan melanggar aspek syariah dalam proses analisa pembiayaan. Misalnya, pada saat pihak bank melakukan bi checking diketahui nasabah pernah menerima pembiayaan dari bank lain dan tingkat kolektabilitasnya tinggi, dan setelah dikonsultasikan dengan bank yang bersangkutan diketahui nasabah terlibat pembiayaan macet di bank tersebut, hal ini menunjukkan kemauan (willingness) dari CN kurang untuk memenuhi kewajibannya. Ataupun saat tahap screening data-data nasabah diketahui ada salah satu identitas nasabah yang dipalsukan atau berbeda dengan identitas yang lain, setelah dikonfirmasi benar data tersebut dimanipulasi, maka karakter $\mathrm{CN}$ seperti ini terlalu beresiko untuk diberikan pembiayaan. Selain itu, saat menganalisa laporan keuangan usaha atau gaji yang diterima CN mungkin diketahui penghasilan yang diterima tidak tetap setiap bulannya, atau tidak mencukupi untuk membayar pinjaman secara berkala dan konsisten. Maka pihak bank tentu tidak akan mau mengambil resiko pembiayaan dari CN yang demikian.

Berdasarkan hasil analisa yang telah dilakukan dan dirangkum dalam LKN, MUP, dan LPBJ maka selanjutnya UFO akan mengajukan semua berkas pembiayaan CN kepada Unit Head yang selanjutnya disebut UH. Dalam realisasinya UH akan melihat kelengkapan berkas pembiayaan yang diajukan oleh UFO, kemudian menyetujui usulan pembiayaan tersebut. Dalam proses ini pihak yang berwenang mengotorisasi akan memutuskan apakah pembiayaan disetujui sepenuhnya sesuai dengan permohonan nasabah atau akan diturunkan jumlahnya.

Apabila UH menyetujui usulan pembiayaan yang diusulkan oleh UFO maka UH akan membuat LKN UH sekaligus menandatangani semua berkas. Tahapan selanjutnya UH akan menentukan persetujuan plafond sesuai dengan limit BWPP. Jika plafond yang 
diusulkan disetujui maka UFO akan meregistrasi status proposal dan membuat Surat Persetujuan Pembiayaan (SP3). Sebaliknya, jika tidak disetujui maka UFO akan meregistrasi status aplikasi reject dan berkas aplikasi pembiayaan disimpan di tempat yang aman.

Dalam melaksanakan kegiatan pemutusan dan otorisasi, BRI Syariah menetapkan delegasi di tiap jenjang unit kerja pembiayaan. Ini dimaksudkan untuk menghindari penyalahgunaan wewenang dalam menentukan besarnya pembiayaan. Penetapan limit kewenangan tersebut adalah sebagai berikut:

1. Pembiayaan Rp 25-75 juta harus mendapat persetujuan atau wewenang dari Unit Head Micro Syariah (UH) / Pincapem/ MMM (Micro Marketing Manager)

2. Pembiayaan di atas Rp 75 juta harus mendapat persetujuan dari Pimpinan Cabang.

\section{Tahap Pencairan/ Akad perjanjian \\ Pemberitaan Permohonan Pembiayaan}

Jika permohonan pembiayaan yang diajukan oleh CN sudah diotorisasi maka pihak SO akan menghubungi nasabah untuk memberitahukan bahwa permohonan pembiayaan telah disetujui. Pihak SO menghubungi CN lewat telepon dan meminta CN datang ke bank untuk melakukan akad pembiayaan sekaligus pengikatan jaminan serta meminta nasabah untuk membawa dokumen-dokumen asli persyaratan di awal pengajuan pembiayaan juga meminta nasabah untuk membawa surat kepemilikan asli jaminan.

Nasabah akan datang ke bank didampingi istri/suaminya dan melakukan akad dengan UFO, UH, dan notaris/delegasi notaris. Nasabah akan menandatangani SP3 dan diverifikasi oleh UFO, kemudian memberikan semua dokumen asli beserta dokumen jaminan asli dan diterima langsung oleh UFO.

Tahapan selanjutnya UFO akan menerima dan memverifikasi dokumen asli milik nasabah dengan cara mencocokkannya dengan copy dokumen pembiayaan yang diberikan nasabah pada saat screening. UFO juga membuat dan menandatangani Surat Bukti Serah Terima Jaminan (BSTJ), kemudian akan diserahkan kepada UH untuk ditandatangani. Setelah semuanya sesuai UFO akan menandatangani lagi DCL untuk memastikan semuanya lengkap dan sesuai.

Setelah semua dokumen sudah diverifikasi, serah terima jaminan sudah selesai, maka UH, UFO, dan nasabah akan melakukan akad pembiayaan dengan menandatangani dokumen akad pembiayaan. Setelah penandatanganan dokumen akad pembiayaan, pihak SO akan menyampaikan salinan akad pembiayaan, pengikatan jaminan, juga BSTJ yang sudah selesai ditandatagani oleh semua pihak. Semua kegiatan yang berlangsung pada saat akad pembiayaan akan di dokumentasikan sebagai arsip sekaligus bukti bagi pihak bank.

\section{Pembukaan Rekening Pembiayaan}

Setelah akad selesai dilakukan, nasabah akan didampingi SO untuk membuka rekening tabungan di customer service yang selanjutnya disebut CS. CS akan melakukan create CIF dan membukakan rekening tabungan mikro untuk hasil realisasi akad, pendebetan biaya-biaya dan pembayaran angsuran.

Pada saat menyetorkan setoran awal pembukaan tabungan, nasabah biasanya akan menyetorkan juga biaya-biaya yang harus diperlukan sebelum pencairan. Hal ini dimaksudkan agar pada saat pencairan jumlah uang yang diterima nasabah sesuai 
Jurnal Ekonomi dan Perbankan Syariah

Vol. 3. No.1, April 2015: 37-54, ISSN (Print): 2330-2703

dengan jumlah yang diajukan. Selain itu, agar nominal yang tertera dalam bukti pencairan adalah senilai dengan nominal pengajuan pembiayaan $\mathrm{CN}$ untuk memperkuat bukti transaksi pembiayaan bagi pihak bank jika suatu saat terjadi wanprestasi.

\section{Pencairan Akad}

Pembiayaan dapat dicairkan jika permohonan pembiayaan telah ditandatangani, pengikatan jaminan telah dilakukan, nasabah telah melunasi biaya-biaya dan seluruh aspek yuridis. Setelah proses akad UFO akan membuat Instruksi Realisasi Pembiayaan yang selanjutnya disebut IRP dan menandatanganinya, IRP dibuat sesuai kondisi yang ada pada MUP. Selanjutnya UFO akan mengumpulkan IRP, DCL, dokumen pembiayaan dan jaminan asli, serta BSTJ dan melakukan pengecekan kelengkapan dokumen sesuai DCL serta menandatanganinya, dan menyusun berkas pembiayaan sesuai ketentuan. Setelah semuanya disusun UFO akan menyerahkan berkas pembiayaan kepada UH.

UH akan memastikan isi IRP sudah sesuai dengan MUP, kelengkapan dokumen asli pada DCL sesuai dengan ketentuan dan menandatangani IRP. Kemudian akan semua dokumen akan diotorisasi oleh Pimpinan Cabang Pembantu. setelah selesai selanjutnya pencairan akan di proses oleh Branch of Supervisor yang selanjutnya disebut BOS. BOS akan melakukan Create Financing Account dan membukukan realisasi pembiayaan, kemudian melaporkan hasil realisasi setiap akhir hari sesuai berita realisasi sebagai konfirmasi bahwa IRP telah dijalankan. UFO akan membuat rekap hasil realisasi per hari dan wajib melakukan rekonsiliasi hasil realisasi setiap akhir hari berdasarkan informasi dari B.O.S.

Jeda waktu antara akad menuju pencairan dana umumnya 3 hari dan maksimal 5 hari. Pada umumnya di kantor cabang yang lebih besar, IRP harus di cek oleh financial support atau asisten pembiayaan, tapi untuk cabang Prabumulih belum memiliki asisten pembiayaan sehingga tugasnya diambil alih oleh UFO

\section{SIMPULAN}

Berdasarkan hasil analisa, dapat disimpulkan bahwa proses analisa kelayakan pembiayaan yang diajukan calon nasabah memiliki prosedur yang mengedepankan prinsip kemudahan, kecepatan, kehati-hatian dan aman dengan lima tahapan pembiayaan, yaitu: permohonan pembiayaan, pengumpulan berkas, analisa kelayakan pembiayaan, keputusan pembiayaan, dan pencairan pembiayaan. Analisa kelayakan pembiayaan mikro pada BRISyariah cabang Prabumulih dilakukan dengan menganalisa enam aspek yang dikenal dengan nama " $5 \mathrm{C}+\mathrm{S}$ ", yaitu character, capasity, capital, collateral, condition of economy, dan syariah. Namun pada implementasinya lebih ditekankan pada aspek character, capasity, dan collateral. Kemudian didukung pula oleh aspek condition of economy, capital, dan syariah.

Selain keenam aspek diatas, BRISyariah cabang Prabumulih juga memberikan kemudahan bagi calon nasabah pembiayaan, juga selalu berusaha untuk mengefektifkan waktu untuk menganalisa kelayakan pembiayaan calon nasabah, biasanya waktu yang dibutuhkan paling cepat adalah tiga hari dan paling lama satu minggu.

Untuk Penelitian selanjutnya, dianjurkan untuk menganalisa perbandingan antara prosedur kelayakan pembiayaan mikro yang dilakukan oleh bank BRISyariah dan bank syariah lainnya, masuk didalamnya analisa proses pendampingan dan monitoring bank syariah terhadap nasabah pembiyaaan mikro. 


\section{DAFTAR PUSTAKA}

Brisyariah (2013). Publikasi Laporan Keuangan Tahunan BRISyariah. www.brisyariah.co.id.

Amin, M. (1992). Mengembangkan Bank Islam di Indonesia . Jakarta : Bangkit.

Anshary, A. G. (2006). Gadai Syariah. Yogyakarta: Gajah Mada University Press.

Antonio, M. S. (2001). Bank Syariah: Dari Teori ke Praktik. Jakarta: Gemani Insani Press.

Antonio, M. S. (2001). Bank Syariah-Dari Teori ke Praktik. Jakarta: Gema Insani.

Bank Indonesia. (2013). Outlook Perbankan Syariah. Retrieved from Bank Indonesia: http://www.bi.go.id/

Bank Indonesia. (2014). Outlook Perbankan Syariah. Retrieved from Publikasi Bank Indonesia: http://www.bi.go.id/id/ruang-media/siaran pers/ Default.aspx

Bank Indonesia. (n.d.). Perbankan Syariah. Retrieved from Bank Indonesia: http://www.bi.go.id/id/perbankan/syariah/

Biro Riset Info Bank . (2014). The Best Sharia Finance Institutions 2014. Jakarta: Info Bank.

Briefcase Book Edukasi Profesional Syariah. (2005). Cara Mudah Memahami Akad - Akad Syariah. Jakarta: REINASAN.

brisyariah.co.id. (2013). Laporan Tahunan. Retrieved from BRISyariah: http://www.brisyariah.co.id/?q=laporan-tahunan

Darmaes, H. (2014, Juli 8). Persyaratan pengajuan pembiayaan di BRISyariah cabang Prabumulih. (S. Safitri, Interviewer)

Hadinoto, S. (2007). Microfinance . Jakarta : PT Elex Media Komputindo.

Hesti, R. (2013). Sistem Informasi Perbankan Syariah. Jakarta: UIN JAKARTA PRESS.

Ikatan Bankir Indonesia. (2014). Memahami Bisnis Bank Syariah. Jakarta: PT Gramedia Pustaka Utama.

Ismail. (2011). Perbankan Syariah. Jakarta: PRENADAMEDIA GROUP.

Isnawati Rais \& Hasanudin. (2011). Fiqh Muamalah dan Aplikasinya pada Lembaga Keuangan Syariah. Jakarta: Lembaga Penelitian UIN Syarif Hidayatullah.

Jusuf, J. (2014). Analisis Kredit untuk Account Officer. Jakarta: PT Gramedia Pustaka Utama.

Karim, A. (2009). Fiqh Muamalat dan Perbankan Syariah. Seminar Syariah Islam. Jakarta: Muamalat Institute.

Muhtasib \& M Nadratuzzaman \& AM Hasan Ali \& Bahrul. (n.d.). Materi Dakwah Ekonomi Syariah. Jakarta: PKES.

Nurul Huda \& Mohamad Heykal. (2010). Lembaga keuangan islam : Tinjauan teoritis dan praktis,. Jakarta: Kencana Prenada media group.

Pratiwi, F. (2014, November 17). Republika Online. Retrieved januari 2, 2015, from http://m.republikaonline.co.id/berita/koran

Pusat Komunikasi Ekonomi Syariah (PKES). (n.d.). Buku Saku Perbankan Syariah. PKES.

Setiawan, A. A. (2014, desember 28). Target Penyaluran Pembiayaan Mikro. (S. Safitri, Interviewer)

Sudarsono, H. (2003). Bank dan Lembaga Keuangan Syariah. Yogyakarta: Ekonisia.

Sutedi, A. (2009). Perbankan Syariah: Tinjauan dan Beberapa Segi Hukum. Jakarta: Penerbit Ghalia Indonesia.

Syafei, R. (2001). Fiqh Muamalah. Bandung: CV Pustaka Setia.

Tambunan, D. T. (2009). UMKM di Indonesia . Bogor : GHALIA INDONESIA.

Usaha Mikro . (n.d.). Retrieved from Kemenkop dan UKM RI: http://www.depkop.go.id/

Violeta, C. (2014, Juli 8). Alur Proses Pembiayaan Mikro Cabang Prabumulih. (S. Safitri, Interviewer) 